\title{
Antibacterial Activity of Sidaguri Plant Extracts (Sidarhombifolia L.) against Oral and Dental Bacteria
}

\author{
Tita Juwitaningsih ${ }^{1}$, Sri Adelila Sari ${ }^{2}$, Siti Chairunisa ${ }^{3}$, Iis Siti Jahro ${ }^{4}$ \\ \{juwitaningsih@unimed.ac.id ${ }^{1}$ \} \\ Department of Chemistry, Faculty of Mathematics \& Science, Medan State University, Medan, \\ 20221, Indonesia ${ }^{1,2,3,4}$
}

\begin{abstract}
Dental and oral diseases can be caused by Staphylococcus aureus, Enterococcus faecalis and Streptococcus mutans. This study was aimed to determine the potential of Sidaguri (Sidarhombifolia L.) plantextract against some bacteria, i.e., Staphylococcus aureus, Enterococcus faecalis and Streptococcus mutans. The methods used in determining the inhibition zone and MIC were paper disc diffusion and MIC using dilution methods.Phytochemical test results indicatedthat the Sidaguri plant was contained alkaloids, flavonoids, tannins and saponins. The inhibition zones of antibacterial activity of Sidaguri plant extract against those bacteriawere found to be 7.9;6.8; and $10.3 \mathrm{~mm}$, respectively for S.aureus, E.faecalis and S. mutans. However, the MIC and MBC values for S. Aureus were found to be $625(\mu \mathrm{g} / \mathrm{mL})$ and MIC values for E.faecalis were of $625(\mu \mathrm{g} / \mathrm{mL})$ with MBC values $>5000(\mu \mathrm{g} / \mathrm{mL})$. The MIC and MBC for S. Mutans were up to $1250(\mu \mathrm{g} / \mathrm{mL})$ and $5000(\mu \mathrm{g} / \mathrm{mL})$. This study concluded that $\mathrm{S}$. Rhombifolia was a bactericidal to S.aureus and S.mutant. In addition, it was a bacteriostatic to E.faecalis.
\end{abstract}

Keywords: Antibacterial Activity, Sidaguri, (Sidarhombifolia L.), Oral and Dental Bacteria.

\section{Introduction}

The oral cavity is the first gate in the digestive system. The oral cavity also plays a major role in one's health and well-being. One effort to improve health is to maintain oral and dental hygiene (Nonong, 2014). Based National Basic Health Research in 2013 year, the prevalence of dental and oral health problems in Indonesia was of $25.9 \%$. It might due to the lack of awareness and knowledge of the public about the importance of dental and oral health,so that disease in the oral cavity could be happened (Tampubolon, 2016). People in Indonesia have not considered dental and oral health. People were tended to ignore toothache, even though dental disease was the first type of disease complained by the community and children (Nurhidayat et al,

2012).Dental and oral diseases were also could be caused by Staphylococcus aureus, Enterococcus faecalis and Streptococcus mutans.

Plant of Sidaguriwas belonged to the genus SidaMalvaceae family, which has been used as a traditional medicine, including to treat rheumatism, asthma, influenza, toothache and reduce pain in swelling due to toothache (Kinho et al, 2012; Sari, 2012). Therefore, this study was aimed to report a class of secondary metabolites from Sidaguri (Sidarhombifolia L.) plant in the North Sumatra and antibacterial activity that causes oral and dental diseases. 


\title{
2 Materials And Methods
}

\subsection{Apparatus and Chemicals}

Apparatus used in this study were included analytical balance, a set of glassware, blender, vacuum pump, Buchner funnel,rotary evaporator(Heidolph), vortex, incubator Memmert), autoclave (Tomy), and laminar (B-One). In addition, some chemicals used were acetone (technical), $\mathrm{FeCl}_{3} 10 \%$, acetic acid, amyl alcohol, concentrated $\mathrm{HCl}$, and distilled water. Some reagents such as Mayer, Wagner, and Dragendorff reagents. Other chemicals needed were concentrated $\mathrm{H}_{2} \mathrm{SO}_{4}, \mathrm{NaOH} 10 \%, \mathrm{Mg}$ powder, chloroform, Mueller-Hinton Agarm(MHA) (Oxoid), Mueller-Hinton Broth (MHB) (Himedia), dimethylsulfoxide (DMSO) p.a (Sigma Aldrich), chloramphenicol disc paper (Oxoid), $0.9 \% \mathrm{NaCl}$ bacterial culture EnterococcusfaecalisATCC49619,StaphylococcusaureusATCC25923 andStreptococcus mutansATCC 35668.

\subsection{Plant Extraction}

Preparation of materials and sample extraction

The dried sample was obtained from the store called Herbal Sempurna Sambu. It was blended into a powder to 200 grams in weight, then macerated with acetone for $3 \times 24$ hours. The macerated sample was filtered using a buchner funnel. Furthermore, the filtrate was evaporated using a rotary evaporator to produce an extract.

\subsection{Phytochemical Test}

\begin{abstract}
Alkaloid Test
Test with Mayer reagents. $2 \mathrm{mg}$ of the extract was dissolved in acetone. Than 4-5 drops of Mayer reagent were added. The results were called positive if white precipitate was formed Test with Wagner reagents. two mg of the extract was dissolved in acetone. Drops of Wagner reagents as the amount of 4-5 If a brown precipitate appeared, it meant positive results. Test with dragendorff reagent. A two mg of the extract was dissolved in acetone. Then add 4-5 drops of dragendorff reagent. Positive results are marked as they were red/orange deposits.
\end{abstract}

\section{Test for Flavonoids}

Wastewater test. A twenty mg of acetone extract. Rhombifolia L. was added to $1000 \mathrm{~mL}$ of hot water, boiled for five minutes and filtered with filter paper. The filtrate was put into a test tube and then added with enough magnesium powder with one $\mathrm{ml}$ of concentrated hydrochloric acid and five ml of amyl alcohol. It has strongly shaken, then and allowed to separate. The formation of red in the amyl alcohol layer indicated the presence of flavonoid compounds.

Test with $\mathrm{NaOH} 10 \%$. A two to four $\mathrm{mL}$ of $10 \% \mathrm{NaOHwas}$ added to extractS.rhombifolia L.Positive results were indicated by a yellow change.

\section{SteroideTriterpene}

Test (Liebermann-Buchard test). A 50-100mg ofS.rhombifolia L. extract was placed on a drop plate and acetic acid was added until all the samples were submerged. It was left for 15 minutes, then 6 drops of the solution were transferred into a test tube. After that, a 2-3 drops of concentrated sulphuric acid were added. The colour changes that occur were observed. The 
resulting colour intensity was used as a relative measure of the content of triterpenoids and steroids in the sample. The presence of triterpenoids was indicated by the occurrence of orange or purple red, while the presence of steroids was indicated by the formation of blue.

\section{Tanin}

Test. A $2 \mathrm{gr}$ of extractS.rhombifolia L. Wasput into a test tube and diluted with acetone.After that, 3 drops of $\mathrm{FeCl}_{3} 10 \%$ was added.A positive result when a blackish green precipitate was formed.

\section{Saponin}

Test. A $2 \mathrm{gr}$ ofS.rhombifolia L.extract wasput in a test tube and diluted with $70 \%$ ethanol. After that, a $10 \mathrm{~mL}$ warm water was added, then shaken for 30 minutes. It was left for 10minutes and if the foam was not lost, it was added with concentrated $\mathrm{HCl}$. If there was a constant foam, then it showed positive results.

\section{Antibacterial Activity Test (CLSI, 2012).}

Sample Preparation. Before the antibacterial test, a test solution (sample) was prepared by weighing $100 \mathrm{mg}$ of S.rhombifolia $L$ leaf extract and dissolved in DMSO 100\%. Did dilution amounted 10 times to obtain a $1 \%$ solution in DMSO in $10 \%$. If the sample was not dissolved in $10 \%$ DMSO then dilution was carried out with DMSO in $100 \%$, which was equivalent to $1000 \mu \mathrm{g} / \mathrm{mL}$.

\section{Preparation of Inoculum Suspension.}

The inoculum was prepared based on the growth method by taking 3-5 bacterial colonies using a sterilizedcotton bud, then transferred into a tube which contained $4-5 \mathrm{~mL} 0.9 \% \mathrm{NaCl}$. Furthermore turbidity was adjusted to $0.5 \mathrm{Mc}$.Farland turbidity.

Determination of Inhibitory Zones with Paper Disc Diffusion Method (CLSI-M02-A11, 2012).

It was begun by inserting $100 \mu \mathrm{L}$ of inoclum onto the gel medium, then levelling by using a spider. Let stand for about five minutes. The disc paper which contained the chloramphenicol and empty antibiotics was placed, so that each of the discwas found to be $24 \mathrm{~mm}$ apart on the plate surface. The paper disc was pressed firmly on the surface. It could be ascertained that the disc paper was in direct contact with the gel plate inoculum. On a blank paper disc, it dropped $20 \mu \mathrm{L}$ of test solution and another blank disc paper was dripped with $100 \%$ and $10 \%$ of DMSO solvents. The plate was closed and placed into an incubator at $37^{\circ} \mathrm{C}$ for $18-24$ hours. The emergence of bacterial growth inhibition zones was characterized by the presence of clear areas around the disc paper which was then measured using callipers, so that the diameter of the inhibitory zone of bacterial growth was obtained. The positive control used was a $30 \mu \mathrm{g}$ chloramphenicol antibiotic disc, while the DMSO solvent used as a negative control.

Determination of MIC by micro dilution method(M02-A11 CLSI,2012).

Determination of MIC was carried out by inserting MHB liquid media that has been suspended with bacteria into each microplate hole from the second to the twelfth column as much as $100 \mu \mathrm{L}$. The first column ofmicroplate was filled with $100 \mu \mathrm{L}$ of liquid medium (negative control), while for the second column was filled with $100 \mu \mathrm{L}$ of liquid medium containing bacterial suspension (positive control).A $1000 \mu \mathrm{g} / \mathrm{mL}$ test solution was entered starting from column twelve. The concentration of the test solution was carried out by 
transferring $100 \mu \mathrm{L}$ of solution from the twelfth hole to the eleven hole. From the eleven holes, it was taken as much as $100 \mu \mathrm{L}$ and put into the ten hole. The same thing was done to the third hole. The amount of solution in each hole was of $100 \mu \mathrm{L}$. Micro plate was then incubated at $37^{\circ} \mathrm{C}$ for 24 hours. Positive control used in this study was chloramphenicol with a concentration of $500 \mathrm{mg} / \mathrm{mL}$.

Determination of MBC. MBC determination was carried out by inoculating all test solutions as much as $10 \mu \mathrm{L}$ from each hole from the micro plate, then it was grow on gel MHA media and incubated at $37^{\circ} \mathrm{C}$ for 24 hours.

\section{Results And Discussion}

Extraction. The extraction of samples $(200 \mathrm{~g})$ of Sidaguri plants were carried out by maceration technique with acetone for $3 \times 24$ hours. It has been produced 3.3 gr of green crude extract.Results of phytochemical test were S.rhombifolia L.plant was contained alkaloids, flavonoids, tannins and saponins.

The results of inhibitory zone test can be seen in Table 1.The method used in this determination was the paper disk diffusion method. This method was done by placing paper discs that have been dripped with a test solution on solid media those has been inoculated with bacteria. Bacterial growth was observed to see clear zones around the disc. The choice of this method was due to easy and simple in determining the antibacterial activity of the sample being tested. The disc paper used was $0.6 \mathrm{~cm}$ in diameter.According to Davis and Stout (1971), that the inhibitory area of $>20 \mathrm{~mm}$ or more, meant having very strong antibacterial activity. In addition, the resistance area was of 10-20mm (strong antibacterial activity), 5$10 \mathrm{~mm}$ (moderate activity), and below $5 \mathrm{~mm}$ (weak activity).

Table 1.Inhibitory Zone Results of S. Hombifolia L.Extract.

\begin{tabular}{llcl}
\hline & S.aureus & E.faecalis & S.mutans \\
\cline { 2 - 4 } & \multicolumn{3}{c}{ Inhibitory Zone $(\mathrm{mm})$} \\
\hline DMSO 10\% & 0 & 0 & 0 \\
Kloramfenik & 33,8 & 9,3 & 26 \\
S. rhombifolia L.extract & 7,9 & 6,8 & 10,3 \\
DMSO 10\% & 0 & 0 & 0 \\
\hline
\end{tabular}

Determination of the Inhibitory Zone. Fig.1 (a) shows the inhibitory zone, whereas in the medium category to inhibit the growth ofS. Aureusbacteria.Likewise forE.faecalis bacteria which have an inhibition zone of $6.8 \mathrm{~mm}$ as Fig.1 (b). While inS. mutans bacteria, the inhibitory zone was formed in $10.3 \mathrm{~mm}$ (Fig.1c) indicatedthat it has strong potential to inhibit bacterial growth. A positive control was chloramphenicol. Inhibitory zone against the bacteria were S. aureus, andS. MutansE.faecalis of 33.8mm (Fig.1a); $9.3 \mathrm{~mm}$ (Fig.1b), and 26mm (Fig.1c), respectively. The difference in diameter of the inhibitory zone between extracts with chloramphenicol standard used was likely because the extract was still a crude extract, so affected to its ability to inhibit bacterial growth. 


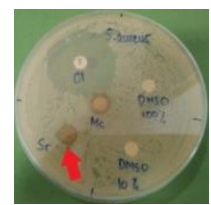

(a)

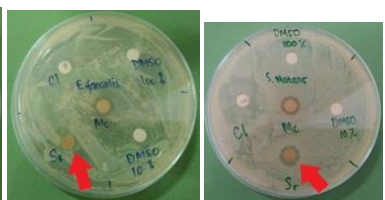

(b) (c)

Fig. 1.The Results of inhibition zone test on:

(a)S. aurens, (b) E. faecalis, and (c) S. mutans

Determination of MIC and MBC.Based on Table 3, acetone extract in all parts of the sidaguri plant with a concentration of $10,000 \mu \mathrm{g} / \mathrm{mL}$ has an inhibitory zone of $7.8 \mathrm{~mm}$. An extract was categorized as active, if the MIC value was $<100 \mu \mathrm{g} / \mathrm{mL}$, medium $(100<\mathrm{MIC}<625 \mathrm{ug} / \mathrm{mL}$ ), and was not active if the MIC value was $>625 \mu \mathrm{g} \mathrm{mL}$ (Dzoyemet al, 2012).Based on Table 3,the MIC value of S.rhombifolia $L$ extract was of $625 \mu \mathrm{g} / \mathrm{mL}$ in the medium category against $S$. Aureus and E. faecalis. However,it has been found that 1250 bacteria against $S$. Mutans with inactive category.

According toPankey and Sabbath (2004), the ways of antibacterial working werebacteriostatic and bactericidal. The results of the determination of MIC and MBC of sidaguri plants can be seen in Table 2 .

Table 2.MIC and MBC values of S. rhombifolia L. extract against test bacteria

\begin{tabular}{lllllll}
\hline & \multicolumn{2}{c}{ S. aureus } & \multicolumn{2}{c}{ E. faecalis } & \multicolumn{2}{c}{ S. mutans } \\
\hline & MIC & MBC & MIC & MBC & MIC & MBC \\
\hline & $\mu \mathrm{g} / \mathrm{mL}$ & & & & & \\
Chloramphenicol & 0,48 & 7,8 & 7,8 & 250 & 0,97 & 125 \\
S. rhombifolia L. & 625 & 625 & 625 & $>5000$ & 1250 & 5000 \\
\hline
\end{tabular}

Value of MBC extract of S. rhombifolia L.was amounted to $625 \mu \mathrm{g} / \mathrm{mL}$ against S.aureus bacteria which meantat $625 \mu \mathrm{g} / \mathrm{mL}$ could not only inhibit but also could be killed (bactericidal).As for the E.faecalis bacteria, the MBC value wasextracted S. rhombifolia L.to be $>5000 \mu \mathrm{g} / \mathrm{mL}$ meant sidaguri was only inhibitory (bacteriostatic).

The values of MBC extract of S.rhombifolia L.was found to be $5000 \mathrm{mcg} / \mathrm{mL}$ against S. Mutans bacteria,which means rhombifolia S. L.extract was a bactericidal with two fold-killing ability of the ability to block it.Based on the phytochemical screening results, all parts of the S. rhombifolia L. Plant contained alkaloids, flavonoids, tannins and saponins. Based on literature studies, Sidaguri plants contain alkaloid alkaloid indoquinolincompounds that were isolated from the plant Sidaguri, namely quindolinone;11-methoxy-quindoline; quindoline[10], so that the possibility of these compounds acting as antibacterials. The alkaloid mechanism that was suspected by disrupting the constituent components of peptidoglycan in bacterial cells, so that the cell wall layer was not formed intact and causes the cell death (Ajizah, 2004). However, S. rhombifolia L. also contained flavonoid compounds namely flavonol-3-O-Galactose (Jubahar et al, 2013). Kaempferol; kaempferol-3-O- $\beta$-D- 
glycosyl-6"- $\alpha$-D-rhamnose (Ajizah, 2004), were likely to act as an antibacterial. The mechanism of action of flavonoids in inhibiting bacterial growth, namely flavonoids, causes damage to the permeability of bacterial cell walls (Kurniawan, 2015).

S. rhombifolia L.also contained tannins and saponins (Wake et al, 2013; Heinichen et al, 2017; Azad et al,2017). The mechanism of action of saponins was included in the antibacterial group which disrupts the permeability of bacterial cell membranes, which results in damage to cell membranes. It could be caused the release of various important components in bacterial cells namely: proteins, nucleic acids and nucleotides Based on research (Nurhidayat et al, 2012). The mechanism of the action of tannin as an antibacterial by causing the cell would become lysis (Ngajow et al, 2012).

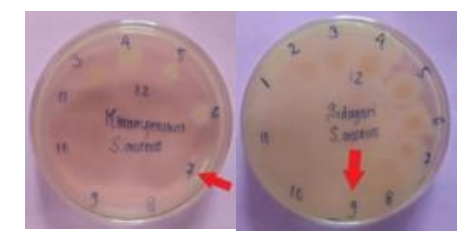

(a)

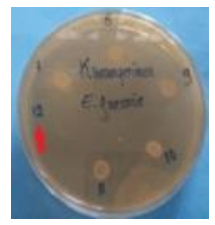

(d) (b)

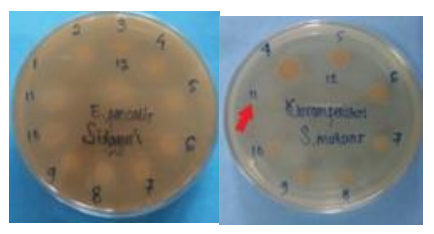

(e)

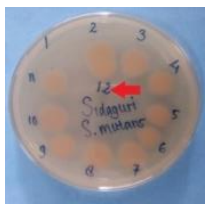

(c)

Fig. 2.MBC test results: (a) Chloramphenicol; (b) Sidaguri extract against S.aureus bacteria; (c) Chloramphenicol; (d) Sidaguri extract against E.faecalis; (e) Chloramphenicol; (f) Sidaguri extract against S.mutans.

\section{Conclusions}

Based on phytochemical tests that have been carried out, the secondary metabolites found in plants ofS.rhombifolia L.was an alkaloid, flavonoid, tannin and saponin. Extracts ofS.rhombifolia L.have the potential as an antibacterial agents. The best activity againstS.aureusandE.faecalis MIC values were found to be $625 \mu \mathrm{g} / \mathrm{mL}$ and $625 \mu \mathrm{g} / \mathrm{mL}$.Extract of S.rhombifolia $L$ was a bactericidal action against S.aureus and bacteriostatic to E.faecalis.

ACKNOWLEDGEMENT.Thanks to the Directorate General of Research and Development Strengthening, Ministry of Research Technology and Higher Education, Republic of Indonesia, which has provided funding for this research through "Basic Higher Education Research (PTUPT)" in 2018 year. 


\section{References}

[1]Nonong,Y.H.,(2014).,Gigi SehatSejakDalamKandunganSampaiUsiaTua, ProsidingTemuIlmiah Bandung Dentistry Tahun 2014 di Bandung: 260.

[2]Tampubolon, N.S., (2016), Dampak Karies Gigi dan Penyakit Periodontal Terhadap Kualita Hidup:http://library.Usu. ac.id/download/ebook/Nurmala\%20Situmorang.pdf.

[3]Nurhidayat, O., Tunggul, E.P., danWahyono, B., (2012), Perbandingan Media Power Point Dengan Flip Chart dalamMeningkatkanPengetahuanKesehatan Gigi danMulut, Journal of Public Health 1(1).

[4]Kinho, J., Arini, D.I.D., Tabba, S., Kama, H., Shabri, S., Kafiar, Y., danKarundeng, M.C., (2011), TumbuhanObatTradisional di Sulawesi Utara Jilid I, Ristek, Manado.

[5]Sari, E.R., (2012), SkriningAktivitasAntimikrobadariDaunTumbuhanSidaguri, JurnalScientia 2 (1): 41-44.

[6]Clinical and Laboratory Standards Institute (CLSI), (2012), Performance Standards for Antimicrobial Disk Susceptibility Tests; Approved Standard-Eleventh Edition CLSI document M02A11, Clinical and Laboratory Standards Institute, USA.

[7]Davis, W.W., and Stout, T.R., (1971), Disc Plate Method of Microbiological Antibiotic Assay, Applied Microbiology 22 (4): 659-665.

[8]Dzoyem, J.P., NKuete, A.H.L., Kuete, V., Tala, M.F., Wabo, H.K., Guru, S.K., Rajput, V.S., Sharma, A., Tane, P., Khan, I.A., Saxena, A.K., Laatsch, H., Tan, N.H., (2012), Cytotoxity and Antimicrobial Activity of the Methanol Extract and Compounds from Polygonumlimbatum, Planta Med 78: 787-792.

[9]Pankey, G. A., danSabath, L.D., (2004), Clinical Relevance of Bacteriostatic versus Bactericidal Mechanisms of Action in the Treatment of Gram-Positive Bacterial Infections, Clinical Infectious Diseases 38: 864-870.

[10]Chaves, O.S., Teles, Y.C.F., Monteiro, M.M.O., Junior, L.G.M., Agra, M.F., Braga, V.A., Silva, T.M.S., Souza, M.F.V., (2017), Alkaloids and Phenolic Compounds from Sidarhombifolia L. (Malvaceae) and Vasorelaxant Activity of Two Indoquinoline Alkaloids, Molecules 22 (94): 1-9.
[11]Ajizah,
A.,
(2004),
Sensitivitas Salmonella

TyphimuriumTerhadapEkstrakDaunPsidiumGuajavaL., Bioscientiae 1 (1): 31-38.

[12]Jubahar, J., Hayati, H., danKrisyanella., (2010), Isolasi Flavonoid dariHerbaSidaRhombifolia, Linn, JurnalFarmasiHigea, 2 (1): 13-18.

[13]Kurniawan, B., Aryana, W.F., (2015), Binahong(Cassia alata L) as Inhibitor of Escherichia coli, J Majority 4 (4): 100-104.

[14]Wake, R.R., Shinde, S.N., Patil, N.A., Halde, U.K., (2013), Preliminary Phytochemical Analysis and Confirmation of Secondary Metabolites by HPTLC Fingerprinting Method of Some Important Plant Species of Genus Sida, International Journal of Pharmaceutical Research and Development 5 (3): 207 212.

[15]Heinichen, O. Y., Hellión-Ibarrola, M.C., Montalbetti, Y., Velázquez, A.M., Dölz-Vargas, J.H., Ibarrola, D.A., (2017), Behavioral Profile and Gastrointestinal Evaluation of the Hydro-Alcoholic Extract of Sidarhombifolia L. (typycháhû) in Mice, Journal of Applied Pharmaceutical Science 7 (7): 021-029.

[16]Azad, A.K., Islam, O., Khairuzzaman, M., Ferdous, J., Shaheen, S.M., (2017), Hypoglycemic, Analgesic and Anti-Inflammatory Activities of Methanol Extract of SidaRhombifolia L. Leaves on Experimental Mice, International Journal of Pharma Sciences and Scientific Research 3 (7): 82-87.
[17]Ngajow,
M.,
Abidjulua,
J., Kamua,
V.S.,
(2013),

PengaruhAntibakteriEkstrakKulitBatangMatoa(Pometiapinnata)terhadapBakteriStaphylococcus aureussecarain vitro, JurnalMipaUnsrat Online 2 (2): 128-132. 